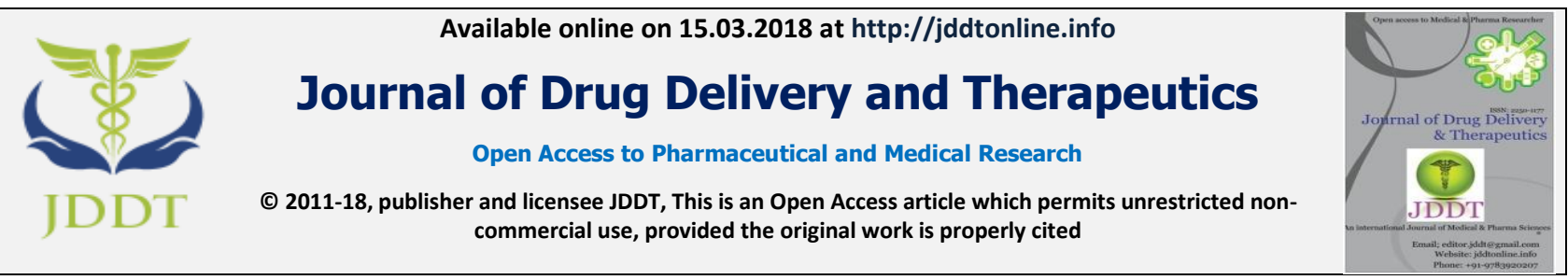

Open $\odot$ Access

Research Article

\title{
Synthesis and antihyperlipidemic activity of Dibenz[c,e]azepine-5,7-dione derivatives in Triton WR-1339-induced hyperlipidemic rats
}

\author{
Minakshi Verma ${ }^{1 *}$, Ashish Kumar Gupta ${ }^{2}$, Ravindra Nath Thakur ${ }^{3}$ \\ ${ }^{1}$ Assistant Professor, Department of Pharmacy, G.S.V.M. Medical College Kanpur U.P., India \\ ${ }^{2}$ Assistant Professor, Department of Pharmacy, V.B.S.Purvanchal University Jaunpur U.P., India \\ ${ }^{3}$ Professor, Department of Pharmacy, G.S.V.M. Medical College Kanpur U.P., India
}

\section{ABSTRACT}

The structural requirements for decreasing cholesterol and triglyceride levels remain largely uninvestigated. Thus a systematic investigation of certain N-substituted dibenz[c,e]azepines is necessary. Nine compounds of N-substituted derivatives of Dibenz[c,e]azepine-5,7-Dione were synthesized and they were tested for antihyperlipidemic activity. Compounds synthesized (C-1, C-3, C-4 and C-5) significantly lowered the serum total cholesterol, triglyceride and LDL (low density lipoprotein) levels and also improved the HDL (high density lipoprotein) level in Triton-WR 1339 induced hyperlipidemic rats.

Keywords: antihyperlipidemic activity, lipids in plasma, high density lipoprotein

Article Info: Received 19 Jan, 2018; Review Completed 11 March 2018; Accepted 11 March 2018; Available online 15 March 2018

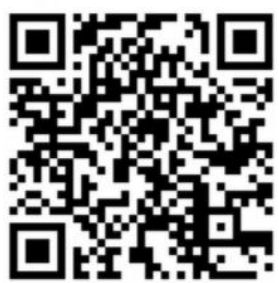

Cite this article as:

Verma M, Gupta AK, Thakur RN, Synthesis and antihyperlipidemic activity of Dibenz[c,e]azepine-5,7-dione derivatives in Triton WR-1339-induced hyperlipidemic rats, Journal of Drug Delivery and Therapeutics. 2018; 8(2):129-135 DOI: http://dx.doi.org/10.22270/iddt.v8i2.1684

${ }^{*}$ Address for Correspondence:

Minakshi Verma, Assistant Professor, Department of Pharmacy, G.S.V.M. Medical College Kanpur U.P., India

\section{INTRODUCTION}

Cardio vascular diseases are leading cause of death in both industrialized and developing nations. It also significantly contributes to the mortality and morbidity of human in the industrialized nations 1,2 . Hyperlipidemia is one of the important risk factors involved in the development of cardiovascular disease. Hyperlipidemia is defined as an elevation of lipids in plasma ${ }^{3}$. Several studies have showed that an intimate correlation exists between coronary heart diseases and hyperlipidemia, consequently a rational approach to the treatment and prevention of coronary heart diseases could be by decreasing any elevated levels of lipids in plasma ${ }^{4,5}$. Although there are many studies have been conducted to evaluate the potential hypolipidemic effects of synthetic and naturally occurring compounds, it is still imperative to find more effective and nontoxic drugs.
In searching for a new class of antihyperlipidemic agents, dibenz[c,e] azepines-5,7-dione derivatives have been found to possess antihyperlipidemic action via lowering the triglycerides and cholesterol levels. The detailed study of cyclic imides showed that sevenmember cyclic imides such as dibenz[c,e]azepines-5,7diones could possess the antihyperlipidemic activity ${ }^{6}$. In the present study, we aimed to synthesize a new series of dibenz(c,e)azepines-5,7-diones derivatives and to investigate their hypolipidemic activity using Triton WR-1339 induced hyperlipidemic rats as a model.

\section{MATERIAL AND METHODS}

\section{Chemicals and instruments}

All chemicals and solvents used were of analytical grade and purchased. The melting points were determined in open capillaries and are uncorrected. Purity of the compounds was checked by thin layer chromatography (TLC). TLC was performed on precoated $(0.25 \mathrm{~mm})$ 
silica gel GF plates (E. Merck, Germany). The infra red spectra were recorded by using ATR-IR model ALPHA Bruker, Germany. 1H NMR spectra were recorded on a BrukerAvance II $400 \mathrm{MHz}$ NMR spectrometer; Chemical shifts are expressed in ppm with reference to TMS.

\section{Animals}

Healthy Wistar male rats weighing 210-230 g were used. The animals had free access to a standard commercial diet and water ad libitum and were kept in rooms maintained at $25{ }^{\circ} \mathrm{C}$ with a 12 -h light/dark cycle. The animals were used after an acclimatization period of 7 days to the laboratory environment. The experiments were performed during the light portion (0800-1600 h). The experimental protocol and procedures used in this study were approved by IAEC of Lachoo Memorial College of Science and Technology, Pharmacy Wing, Jodhpur.

\section{Synthesis and scheme}

The scheme of synthesis of test compounds is presented in Figure 1-2. Diphenic anhydride was prepared from reported procedure. A mixture of diphenic anhydride (11.21 gm, 0.05 mole) and appropriate aromatic and hetro-aromatic amine $(0.05 \mathrm{~mole})$ in Xylene $(150 \mathrm{ml})$ was heated under reflux for 4-5 hours with stirring. The mixture was cooled and the resulting solid product (a diphenic acid derivative) was filtered, dried and transferred to $250 \mathrm{ml}$ RBF containing acetic anhydride $(150 \mathrm{ml})$ and anhydrous sodium acetate (10 gm) equipped with reflux condenser. The mixture was heated for 3-4 hours and transferred to $500 \mathrm{ml}$ ice cooled water. The precipitate was washed with water and crystallized with ethanol ${ }^{7,8}$

The compounds were characterized by qualitative elemental analysis, melting point and spectroscopic analysis ${ }^{9}$. Melting point ranges of newly synthesized compounds were determined by open glass tube using visual melting apparatus and are uncorrected. The temperature at which compound started melting to the temperature at which it completely melted was taken as the melting point range. All the new derivatives were subjected to elemental detection for elements like Chlorine, Nitrogen and Sulphur. Qualitative assessment for the presence of these atoms was done by preparing Lassaign extract of the compounds. IR spectrum of compounds was recorded on an ATR Spectrophotometer. ${ }^{1} \mathrm{H}-\mathrm{NMR}$ spectrum of newly synthesised compounds was recorded on NMR spectrometer at $400 \mathrm{MHz}$ in chloroform and Dimethyl sulfoxide (DMSO) using Tetramethylsilane (TMS) as internal standard. Chemical shift, delta $\delta$ in ppm was recorded.

\section{Triton WR 1339 induced anti-hyperlipidemic activity}

Seventy two rats were arranged in 12 groups (6 animals each) and were deprived of food but were allowed free access to drinking water. Group I treated with vehicle (distilled water) served as normal group, in all other groups (II to XII) hyperlipidemia was induced by a single intraperitoneal (ip) injection of triton WR 1339 $(300 \mathrm{mg} / \mathrm{kg}$ body $\mathrm{wt})$ dissolved in normal saline $(\mathrm{pH} 7.4)$ ${ }^{10}$. Group II was kept as control, without any further treatment. Group III was treated with atorvastatin 10 $\mathrm{mg} / \mathrm{kg}$ body wt. Group IV to XII were treated with Dibenz [c,e] Azepine-5,7-Dione derivatives compound I to IX in dose of $150 \mathrm{mg} / \mathrm{kg}$. The compounds and atorvastatin were administered by oral gavage one hour before the triton administration. Animals were sacrificed $24 \mathrm{~h}$ after the administration. Blood was collected from tail vein of each animal and the serum was separated and used for the estimation of serum lipid profile.

\section{Statistical Analysis}

Results were expressed as mean values and standard deviations. The data were analyzed by one way ANOVA followed by and Dunnett's test with triton control group using Prism 3.0. $\mathrm{P}$ value less than 0.05 were considered significant.

\section{RESULT}

Synthesis and characterization of Dibenz[c,e]azepine5,7-Dione derivatives

Nine derivatives of Dibenz[c,e]azepine-5,7-dione or Diphenimide (C-1 to C-9) were synthesized from Diphenic anhydride or Dibenz[c,e]oxepine-5,7-Dione. Diphenic anhydride was synthesized from anthrinillic acid. Characterization of the synthesized compounds were carried out on the basis of chemical data and spectral data.

Table 1: Melting point, percentage yield, molecular formula and molecular weight of Dibenz [c, e] azepine-5,7-Dione derivatives.

\begin{tabular}{|l|l|l|l|l|l|}
\hline $\begin{array}{l}\text { Compound } \\
\text { No. }\end{array}$ & $\begin{array}{l}\text { Molecular } \\
\text { formula }\end{array}$ & $\begin{array}{l}\text { Melting point } \\
\left.\text { Range ( }{ }^{\mathbf{0}} \mathbf{C}\right)\end{array}$ & \% Yield & $\begin{array}{l}\text { Molecular weight } \\
\text { (Da) }\end{array}$ & $\begin{array}{l}\text { Log P value } \\
\text { (calculated) }\end{array}$ \\
\hline $\mathrm{C}-1$ & $\mathrm{C}_{20} \mathrm{H}_{13} \mathrm{NO}_{2}$ & $203-05$ & 76.84 & 299.32 & $3.79 \pm 0.62$ \\
\hline $\mathrm{C}-2$ & $\mathrm{C}_{22} \mathrm{H}_{15} \mathrm{NO}_{3}$ & $242-48$ & 73.82 & 341.36 & $3.55 \pm 0.63$ \\
\hline $\mathrm{C}-3$ & $\mathrm{C}_{21} \mathrm{H}_{15} \mathrm{NO}_{2}$ & $147-49$ & 68.29 & 313.35 & $4.25 \pm 0.62$ \\
\hline $\mathrm{C}-4$ & $\mathrm{C}_{20} \mathrm{H}_{13} \mathrm{NO}_{3}$ & $250-52$ & 71.04 & 315.32 & $2.96 \pm 0.62$ \\
\hline $\mathrm{C}-5$ & $\mathrm{C}_{20} \mathrm{H}_{14} \mathrm{~N}_{2} \mathrm{O}_{2}$ & $192-94$ & 62.35 & 314.34 & $2.21 \pm 0.63$ \\
\hline $\mathrm{C}-6$ & $\mathrm{C}_{20} \mathrm{H}_{12} \mathrm{~N}_{2} \mathrm{O}_{4}$ & $260-62$ & 74.35 & 344.32 & $4.07 \pm 0.63$ \\
\hline $\mathrm{C}-7$ & $\mathrm{C}_{20} \mathrm{H}_{12} \mathrm{ClNO}_{2}$ & $219-21$ & 67.71 & 333.77 & $4.632 \pm 0.63$ \\
\hline $\mathrm{C}-8$ & $\mathrm{C}_{19} \mathrm{H}_{12} \mathrm{~N}_{2} \mathrm{O}_{2}$ & $238-40$ & 65.93 & 300.31 & $2.80 \pm 0.63$ \\
\hline $\mathrm{C}-9$ & $\mathrm{C}_{20} \mathrm{H}_{14} \mathrm{~N}_{2} \mathrm{O}_{2}$ & $226-28$ & 65.53 & 314.34 & $3.26 \pm 0.63$ \\
\hline
\end{tabular}


Melting point, percentage yield, molecular formula, molecular weight and $\log \mathrm{p}$ of synthesised compounds are shown in Table 1. The Spectroscopic data (IR and
${ }^{1} \mathrm{H}-\mathrm{NMR}$ ) of synthesised compounds are illustrated in Table 2.

Table 2: Spectroscopic data of Dibenz[c,e]azepine-5,7-Dione derivatives

\begin{tabular}{|c|c|c|c|}
\hline Comp. & Structure & Characterisitc IR (KBr) $\mathbf{C m}^{-1}$ & NMR Chemical Shift $\delta(p p m)$ \\
\hline $\mathrm{C}-1$ & & $\begin{array}{l}\text { 1600-1400 Str. }(\mathrm{C}=\mathrm{C} \text { of aryl }) \\
1655 \text { Str. }(\mathrm{C}=\mathrm{O} \text { Imide }) \\
\text { 3150-3000 (Str. Ar C=C-H Str. })\end{array}$ & $\begin{array}{l}6.51-7.44(\mathrm{~m}, 5 \mathrm{H}, \mathrm{N}-\mathrm{Ar}-\mathrm{H}) \\
7.76-8.21(\mathrm{~m}, 8 \mathrm{H}, \text { Ar-H })\end{array}$ \\
\hline $\mathrm{C}-2$ & & 1690 Str. (Ar C=O ) & $\begin{array}{l}2.54\left(\mathrm{~s}, 3 \mathrm{H}, \mathrm{COCH}_{3}\right) \\
7.78-7.80(\mathrm{~m}, 4 \mathrm{H}, \mathrm{N}-\mathrm{Ar}-\mathrm{H})\end{array}$ \\
\hline $\mathrm{C}-3$ & & $\begin{array}{l}2925 \text { Str. }\left(\mathrm{C}-\mathrm{H} \text { of } \mathrm{Ar} \mathrm{CH}_{3}\right) \\
3030 \mathrm{Str} .(\mathrm{Ar}=\mathrm{C}-\mathrm{H})\end{array}$ & $\begin{array}{l}2.29\left(\mathrm{~s}, 3 \mathrm{H}, \mathrm{CH}_{3}\right) \\
7.22-7.65(\mathrm{~m}, 4 \mathrm{H}, \mathrm{N}-\mathrm{Ar}-\mathrm{H})\end{array}$ \\
\hline $\mathrm{C}-4$ & & 3315 Str. (Phenolic OH) & $\begin{array}{l}7.04-7.38(\mathrm{~m}, 4 \mathrm{H}, \mathrm{N}-\mathrm{Ar}-\mathrm{H}) \\
9.17(\mathrm{~s}, 1 \mathrm{H}, \mathrm{Ar}-\mathrm{OH})\end{array}$ \\
\hline $\mathrm{C}-5$ & & $\begin{array}{l}3445 \mathrm{Str} .\left(\mathrm{Ar} \mathrm{NH} \mathrm{NH}_{2}\right) \\
3360 \mathrm{Str} .\left(\mathrm{Ar} \mathrm{NH} \mathrm{NH}_{2}\right) \\
\text { Due to symmetrical and } \\
\text { asymmetrical stretching }\end{array}$ & $\begin{array}{l}5.85\left(\mathrm{~s}, 2 \mathrm{H}, \mathrm{Ar}-\mathrm{NH}_{2}\right) \\
6.96-6.99(\mathrm{~m}, 4 \mathrm{H}, \mathrm{N}-\mathrm{Ar}-\mathrm{H})\end{array}$ \\
\hline $\mathrm{C}-6$ & & $\begin{array}{l}1360 \text { Str. }\left(\mathrm{N}-\mathrm{O} \text { of } \mathrm{NO}_{2}\right) \\
1521 \text { Str. }\left(\mathrm{N}-\mathrm{O} \text { of } \mathrm{NO}_{2}\right)\end{array}$ & $7.72-8.49(\mathrm{~m}, 4 \mathrm{H}, \mathrm{N}-\mathrm{Ar}-\mathrm{H})$ \\
\hline C-7 & & $\begin{array}{l}842 \mathrm{Str} . \mathrm{C}-\mathrm{Cl}(\mathrm{Ar}-\mathrm{Cl}) \\
1590 \mathrm{Str}(\mathrm{C}=\mathrm{C} \text { of } \mathrm{Ar}) \\
3084 \mathrm{Str} .\left(\mathrm{Ar} \mathrm{C}-\mathrm{H} \text { of } \mathrm{C}_{6} \mathrm{H}_{4} \mathrm{Cl}\right)\end{array}$ & 7.37-7.61 (m, 4H, N-Ar-H) \\
\hline C-8 & & $\begin{array}{l}1670 \text { Str. }(\mathrm{C}=\mathrm{N} \text { of pryridine }) \\
2948-3176 \mathrm{Str} . \text { (=CH of Pyridine) }\end{array}$ & 7.75-8.68 (m, 4H, Pyridine-H) \\
\hline C-9 & & $\begin{array}{l}1662 \text { Str. }(\mathrm{C}=\mathrm{N} \text { of pyridine }) \\
2954-3068 \mathrm{Str} \text {. (=CH of Pyridine) } \\
2850-2750 \mathrm{Str},\left(\mathrm{CH}_{3} \text { of Pyrindine }\right)\end{array}$ & $\begin{array}{l}2.70(\mathrm{~s}, 3 \mathrm{H}, \mathrm{CH} 3 \text { with pyridine }) \\
7.51-8.42(\mathrm{~m}, 4 \mathrm{H}, \text { Pyridine } \mathrm{H})\end{array}$ \\
\hline
\end{tabular}


Table 3: Effect of different derivatives of Dibenz[c,e]azepine-5,7-Dione on serum lipid levels in Triton WR-1339 (TRI) induced hyperlipidemic rats.

\begin{tabular}{|l|l|l|l|l|l|}
\hline Groups & $\begin{array}{l}\text { Treatment dose } \\
(\mathrm{mg} / \mathrm{kg})\end{array}$ & $\begin{array}{l}\text { Total Cholesterol } \\
(\mathrm{mg} / \mathrm{dl})\end{array}$ & $\begin{array}{l}\text { Triglyceride } \\
(\mathrm{mg} / \mathrm{dl})\end{array}$ & $\begin{array}{l}\text { HDL-C } \\
(\mathrm{mg} / \mathrm{dl})\end{array}$ & $\begin{array}{l}\text { LDL-C } \\
(\mathrm{mg} / \mathrm{dl})\end{array}$ \\
\hline Normal & Vehicle & $82.83 \pm 4.64$ & $96.08 \pm 4.37$ & $36.17 \pm 2.95$ & $29.83 \pm 2.37$ \\
\hline Triton control & 300 & $388.17 \pm 6.37$ & $529.08 \pm 7.71$ & $24.33 \pm 1.43$ & $145.33 \pm 5.85$ \\
\hline Triton + Atorvastatin & 10 & $151.17 \pm 6.48$ & $375.17 \pm 5.49$ & $33.42 \pm 1.21$ & $45.17 \pm 2.52$ \\
\hline Triton + C-1 & 150 & $294.33 \pm 18.96^{*}$ & $479.50 \pm 15.44^{*}$ & $29.33 \pm 1.41^{*}$ & $110.17 \pm 8.04^{*}$ \\
\hline Triton + C-2 & 150 & $380.67 \pm 9.26$ & $524.42 \pm 8.60$ & $25.17 \pm 1.11$ & $133.17 \pm 3.72$ \\
\hline Triton + C-3 & 150 & $281.17 \pm 7.32^{*}$ & $433.04 \pm 20.93^{*}$ & $30.67 \pm 0.92^{*}$ & $87.33 \pm 5.27 *$ \\
\hline Triton + C-4 & 150 & $262.33 \pm 7.20^{*}$ & $376.08 \pm 10.92^{*}$ & $32.17 \pm 1.19^{*}$ & $65.50 \pm 1.06^{*}$ \\
\hline Triton + C-5 & 150 & $274.17 \pm 8.42^{*}$ & $426.33 \pm 19.45^{*}$ & $31.33 \pm 1.05^{*}$ & $69.33 \pm 1.99^{*}$ \\
\hline Triton + C-6 & 150 & $391.50 \pm 7.36$ & $517.33 \pm 7.41$ & $24.67 \pm 1.52$ & $138.83 \pm 4.92$ \\
\hline Triton + C-7 & 150 & $368.83 \pm 6.05$ & $519.83 \pm 6.61$ & $25.83 \pm 1.17$ & $139.67 \pm 5.41$ \\
\hline Triton + C-8 & 150 & $386.17 \pm 6.70$ & $516.50 \pm 13.37$ & $25.17 \pm 1.56$ & $135.33 \pm 11.56$ \\
\hline Triton + C-9 & 150 & $372.33 \pm 13.94$ & $501.50 \pm 10.92$ & $26.17 \pm 1.01$ & $140.33 \pm 8.24$ \\
\hline
\end{tabular}

Values reported as Mean \pm SEM $(\mathrm{n}=6)$. The data were analyzed by one way ANOVA followed by and Dunnett test. *P<0.05 as compared with triton control group.

\section{Antihyperlipidemic Activity}

\section{Induction of Hyperlipidemia by Triton WR-1339}

The levels of plasma total cholesterol (TC), triglyceride (TG), high-density lipoprotein (HDL) and low-density lipoprotein (LDL) levels of all groups treated for $24 \mathrm{~h}$ after Triton administration are shown in Table 3. In comparison with the normal group, Triton WR-1339 caused a significant increase in TC, TG and LDL measured $24 \mathrm{~h}$ after Triton injection. Triton WR-1339 caused a significant decrease in HDL cholesterol levels in the hyperlipidemic control (HG), at $24 \mathrm{~h}$ after Triton administration, in comparison with the normal group (Figure 3-6 and Table 3).
Effect of synthesized compounds (C-1 to C-9) on plasma level of Total Cholesterol (TC), Triglyceride (TG) and Low Density Lipoprotein (LDL)

The oral administration of Dibenz[c,e]azepine-5,7-Dione derivatives compound 1,3, 4 and 5 to rats significantly $(\mathrm{P}<0.05)$ decreased the plasma level of TC, TG and LDL in comparison to the triton control group (Figure 3,4,5 and Table 3).

\section{Effect on plasma level of HDL}

The plasma level of HDL-C significantly increased $(\mathrm{P}<0.05)$ in rats treated with compound $1,3,4$ and 5 in comparison to the triton control group (Figure 4 and Table 3).

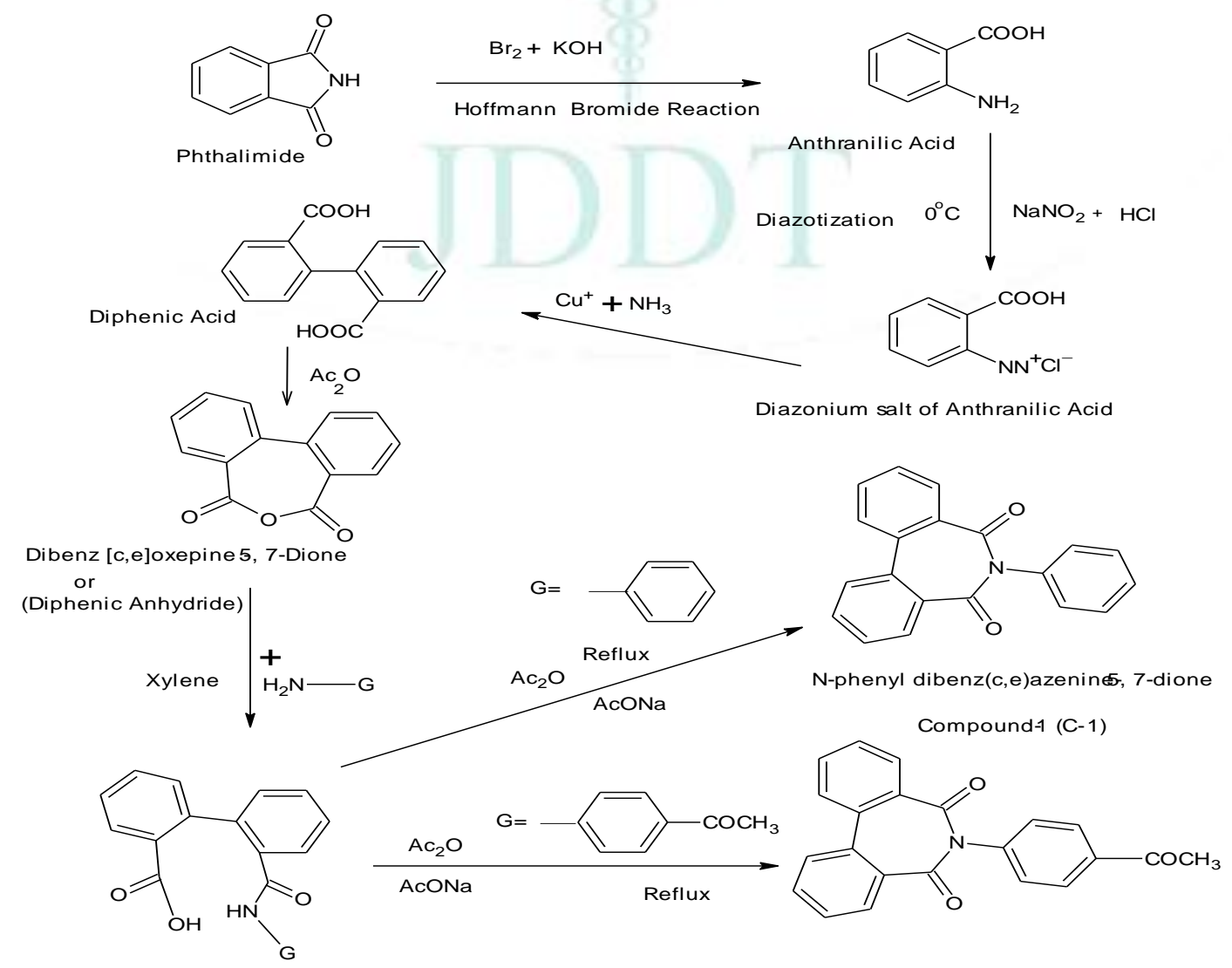

Compound 2 (C-2)

Figure 1: Scheme for synthesis of Dibenz[c,e]azepine-5,7-Dione derivatives compounds one and two 


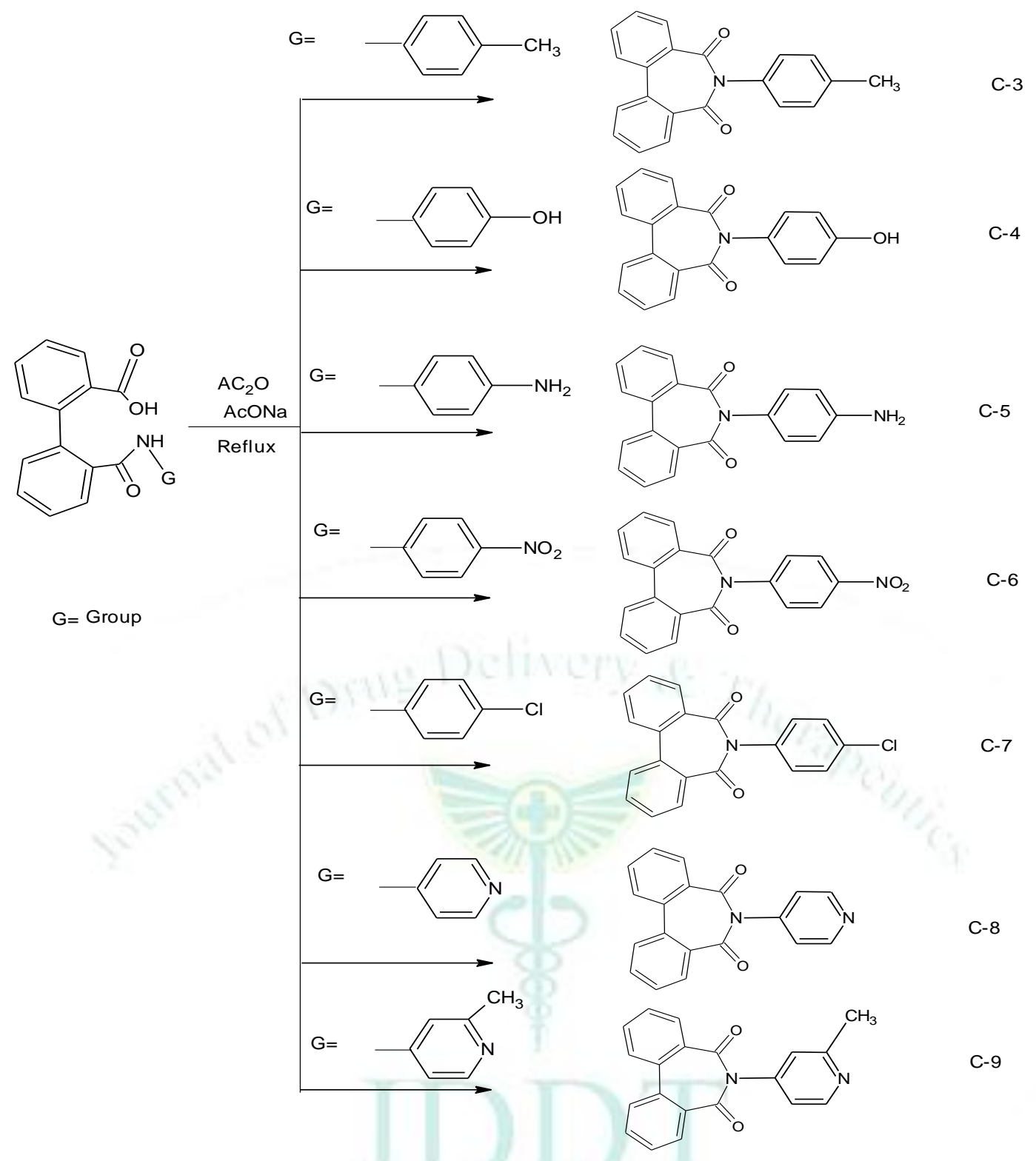

Figure 2: Scheme for synthesis of Dibenz[c,e]azepine-5,7-Dione derivatives compounds three to nine.

Serum Total Cholesterol Level (mg/dl) of Different Treated Groups

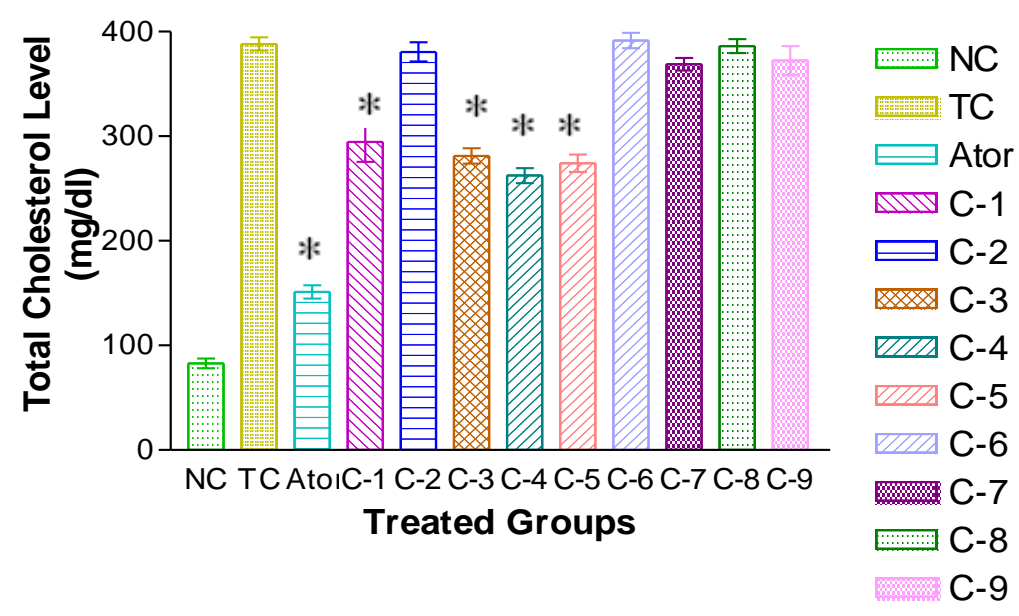

Figure 3: Effect of different derivatives of Dibenz[c,e]azepine-5,7-Dione on total cholesterol in Triton WR-1339 (TRI) induced hyperlipidemic rats. (NC: Normal control, TC: Triton control, Ator: Atorvastatin, C-1,2,3,4,5,6,7,9 : Test compound $1,2,3,4,5,6,7,9), * \mathrm{P}<0.05$ as compared with triton control group. 


\section{Serum HDL Level (mg/dl) in Differente Treated Groups}

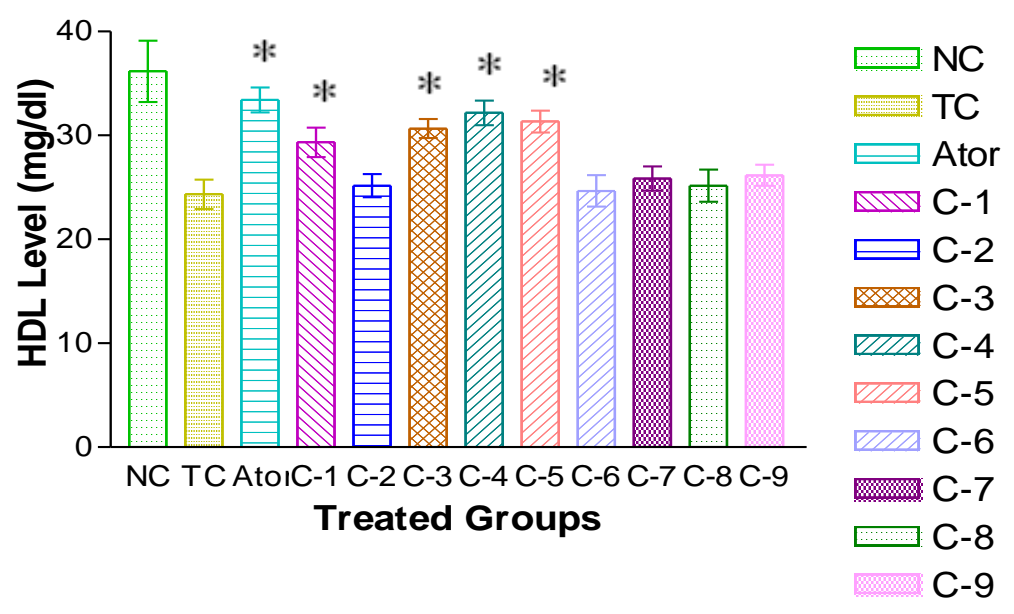

Figure 4: Effect of different derivatives of Dibenz[c,e]azepine-5,7-Dione on HDL level in Triton WR-1339 (TRI) induced hyperlipidemic rats. (NC: Normal control, TC: Triton control, Ator: Atorvastatin, C-1,2,3,4,5,6,7,9 : Test compound $1,2,3,4,5,6,7,9), * \mathrm{P}<0.05$ as compared with triton control group.

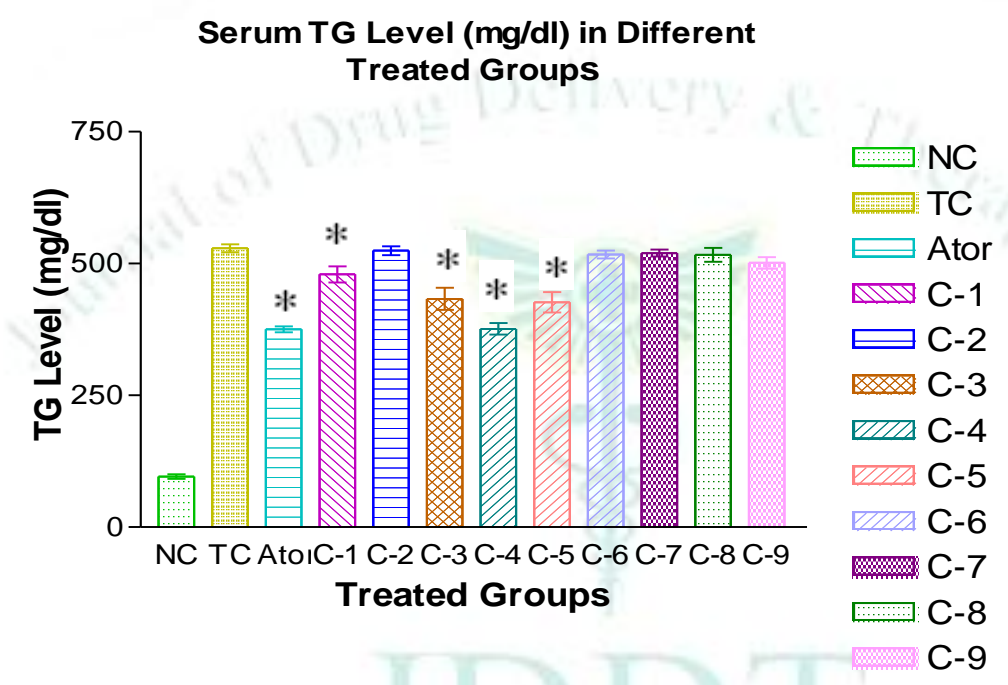

Figure 5: Effect of different derivatives of Dibenz[c,e]azepine-5,7-Dione on triglyceride level in Triton WR-1339 (TRI) induced hyperlipidemic rats. (NC: Normal control, TC: Triton control, Ator: Atorvastatin, C-1,2,3,4,5,6,7,9 : Test compound $1,2,3,4,5,6,7,9), * \mathrm{P}<0.05$ as compared with triton control group.

\section{Serum LDL Level (mg/dl) in Different Treated Group}

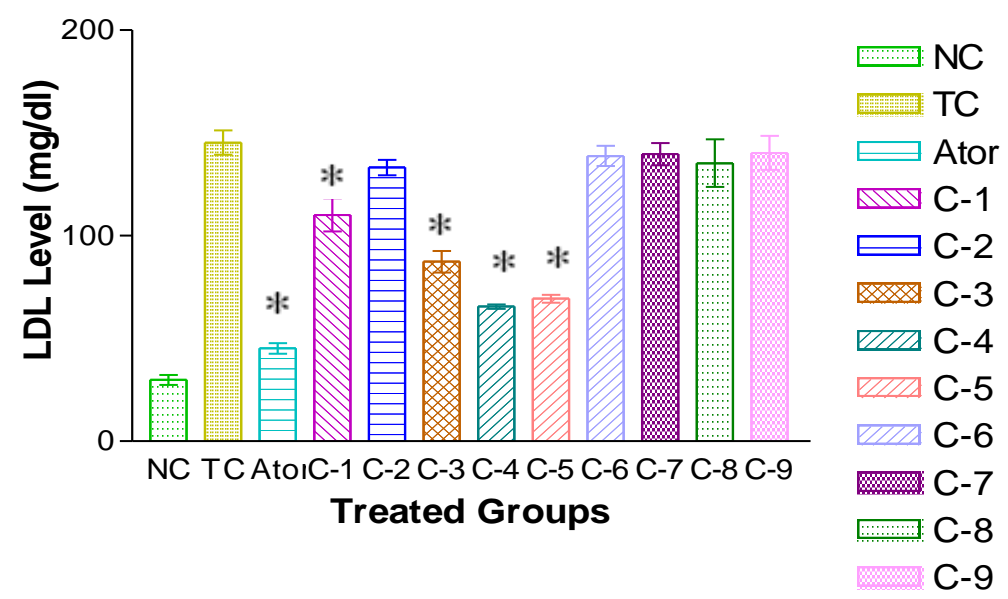

Figure 6: Effect of different derivatives of Dibenz[c,e]azepine-5,7-Dione on LDL level in Triton WR-1339 (TRI) induced hyperlipidemic rats. (NC: Normal control, TC: Triton control, Ator: Atorvastatin, C-1,2,3,4,5,6,7,9 : Test compound $1,2,3,4,5,6,7,9), * \mathrm{P}<0.05$ as compared with triton control group. 


\section{DISCUSSION}

Triton WR-1339 acts as a surfactant and suppresses the action of lipases to block the uptake of lipoproteins from circulation by extra hepatic tissues, resulting into increased blood lipid concentration [Kumar]. The biphasic nature of triton-induced hyperlipidemia is helpful in understanding the mode of action of hypolipidemia agents. Drugs interfering with lipid biosynthesis or uptake will be active in the synthesis phase.

In searching for a new class of antihyperlipidemic agents, many compounds having open imide or cyclic imide function have been found to possess antihyperlipidemic action via lowering the triglycerides and cholesterol levels. Some Dibenz[c,e]azepine-5,7Dione compound are more superior in many cases than clofibrate.

In this study, cholesterol, triglyceride and LDL levels were found to be elevated $24 \mathrm{~h}$ after the triton WR-1339 administration which was effectively decreased by treatment with oral administration of Dibenz[c,e]azepine-5,7-Dione compounds 1,3, 4 and 5. The reduction of plasma cholesterol and triglyceride in test compound treated rats was associated with a decrease in LDL (Patel et al., 2003). These findings suggest that the cholesterol-lowering activity of test compound probably mediated through HMG-CoA reductase activity or lipoprotein lipase activity, responsible to decrease plasma triglycerides levels ${ }^{11}$. However, more studies are needed to identify the exact mechanisms of the compound 1, 3, 4 and 5 .

\section{CONCLUSION}

In conclusion, it may be stated that the results of the present study demonstrated new properties of synthesized derivatives of dibenz[c,e]azepines-5,7diones as potent lipid lowering agents and these beneficial activities may contribute to their cardioprotective and antiatherosclerotic role.

\section{REFERENCES}

1. Ginsberg HN, Stalenhof f, Cardiovasc j. Risk. 2003; 10:121

2. World health organization, Global Status Report on Non Communicable Diseases 2014.

3. McKenney JM, Dyslipiemias Koda-Kimble M.A, Young LY, In Applied Therapeutics, 7th ed.;Eds.; Lippincott Williams and Wilkins: Philadelphia, PA, USA, 2001; pp. 11:1-11:43.

4. Martin MJ; Hulley SB, Browner WS, Kuller LH, Wentworth D, Serum cholesterol, blood pressure, and mortality: implications from a cohort of 361, 662 men. Lancet 1986; 2:933-936.

5. Nelson RH, Hyperlipidemia as a Risk Factor for Cardiovascular Disease. Primary care. 2013; 40(1):195-211.

6. Saber ES, Barakat Mohamed AA, Zahabi El, Synthesis of Certain New Dibenz[c,e]azepine-5,7-diones of Expected Antihyperlipidemic Activity. JKAU: Med. Sci., 2007; 14(4):317.

7. http://www.google.ch/patents/US2693465.

8. http://www.google.ch/patents/US2693465.

9. Robert M. Silverstein, ClaytonC. Bassler and Terrence C. Mossull. Spectroscopic identification of organic compounds. 4th edn. John Wiley \& Sons Inc. USA. (1981).

10. Okazaki M, Suzuki M, Oquchi K, Changes in coagulative and fibrinolytic activities in Triton WR-1339inducedhyperlipidemia in rats. Japanese Journal of Pharmacology. 1990; 52:353-361.

11. Kasim SE, LeBoeuf RC, Khilnani S, Tallapaka L, Dayananda D, Jen KL.Mechanisms of triglyceride-lowering effect of an HMG-CoA reductase inhibitor in a hypertriglyceridemic animal model, the Zucker obese rat. Lipid Res. 1992; 33(1):17.

12. Rosowsky Andre. The Chemistry of Heterocyclic Compounds, Azepines Part 1, Volume 43 Edition, John Wiley, 1984; 579 581 .

13. Wong OT, Murthy AR, Day PA, Calvin J. "The hypolipidemic activity of N(4-methyl-phenyl)diphenimide in rodents". Pharmacol Res Commun 1987; 19(12):839-858. -66666 